\section{Alternate Curricula as a Barrier to Inclusive Education for Students With Intellectual Disabilities}

\author{
Amy Hanreddy ${ }^{a,}{ }^{*}$, Daniel Östlund ${ }^{b}$
}

\begin{tabular}{lr}
\hline Received: & 18 September 2019 \\
Revised: & 16 November 2019 \\
Accepted: $\quad 24$ December 2019 \\
ISSN: $1307-9298$ \\
Copyright @ IEJEE \\
www.iejee.com
\end{tabular}

DOI: 10.26822/iejee.2020358217

\begin{abstract}
Although intellectual disability is a culturally defined and often fluid concept, individuals with this label are often at the greatest risk of isolation and low expectations, particularly within school environments. Despite institutional narratives on educating and raising expectations for "all" students, the use of alternate curricula for individuals with intellectual disabilities creates a structural barrier that explicitly designates students as incapable of using the same curriculum as nondisabled peers. Through exemplars in the United States and Sweden, the authors argue the use and expansion of alternate curricula is an international trend with troubling short- and long-term consequences for students. In Sweden, a national alternative curriculum is required for all students with intellectual disabilities. In the United States, adoption of alternate achievement standards varies by state; yet, the use of alternate curricular materials in self-contained classrooms is widespread despite questionable alignment to general education standards. In addition to the challenges posed by a separate curriculum for students with intellectual disabilities, approaches to promoting authentic engagement and learning in the context of general education settings and curricula are discussed.
\end{abstract}

Keywords: Inclusive Education, Alternate Curricula, Intellectual Disabilities, Curriculum Access

\section{Introduction}

Through several years of conversations, shared time in schools in both the United States and Sweden, and professional work in teacher education, the authors have found the implementation of alternate curricula to be a systemic challenge to inclusive practices in each of our respective countries. Despite the many distinctions between the United States and Sweden in population, cultural practices, educational systems, and teacher preparation, we contend the common challenges we face, and the recommendations to address these challenges, may have relevance beyond our two countries. Our experiences with educators from other countries around the world demonstrate that, although in clusive approaches to teaching students with intellectual disabilities (IDs) have been documented in some places on a national level (Andriichuk, 2017; Carnovali, 2017), these institutionalized structures remain the exception rather than the rule. This troubling international inclination toward exclusion points to the need for additional dialogue to understand better the systems sustaining segregation of people with IDs worldwide. In this conceptual paper, we first examine our historical contexts, respective policies on inclusive education, and literature on current practices. Next, we provide analysis of key issues and barriers related to alternate curricula and inclusive education. Finally, we propose recommendations for how these barriers might be addressed systematically in the areas of educator preparation, pedagogy, and policy.

\section{Intellectual Disability and Segregation in the United} States and Sweden

Individuals with IDs share a complex and difficult history in the United States and Sweden (Barow, 2009; Carey, 2009; Noll \& Trent, 2004; Östlund, 2012). This history includes institutionalization, sterilization (Brantlinger, 1995; Laughlin, 2004), exclusion from public schooling, and segregation in public schools (National Council on Disability, 2018). A variety of labels, definitions, and classifications have been invented and adapted over time to describe perceived cognition and potential (Keith \& Keith, 2013). More recent descriptions of
ID emphasize the interaction between an individual and the environments in which they participate (Shogren, Luckasson, \& Schalock, 2014; Shogren et al., 2017), consistent with international definitions of disability which similarly emphasize the interaction between an individual and their environment (United Nations General Assembly, 2007; World Health Organization [WHO], 2001).

In response to the stigma and prejudice faced by people with IDs for centuries, individuals with IDs and their families, advocates, and allies have engaged in advocacy to secure their rightful places in neighborhoods, schools, and the workplace. For example, individuals with IDs were instrumental in the self-advocacy movement of the 1970s, during which they spoke out about experiences in segregated settings, organized protests and sit-ins, and participated in legislative advocacy (Grim, 2015; Pelka, 2012). In both the United States and Sweden, the principle of normalization helped initiate, change legislation, and lay the foundation for ideas found today in documents such as the International Classification of Functioning (WHO, 2001) and the UN Convention on the Rights of Persons With Disabilities (United Nations General Assembly, 2007). More recently, individuals with IDs have engaged in media campaigns to promote acceptance and address stereotypes (e.g., "Not Special Needs"; McClammy, 2017). Despite many gains, school-age students with IDs remain largely segregated from students without disabilities in both U.S. and Swedish schools (Kleinert et al., 2015; National Council on Disability, 2018; Swedish National Audit Office, 2019; U.S. Department of Education, 2018).

Legal and Policy Frameworks Related to Access to General Education in the United States and Sweden

In both Sweden and the US, several policies have been in place for many years that are consistent with the principles of normalization and inclusive education. In both countries, the movement towards inclusive practices began with the right to education for all school aged students, and was expanded with legislation delineating expectations for learning. 


\section{Access to School}

The vision of inclusive education and "a school for all" was formed early in Swedish education policy (Swedish Government Official Reports, 1948:27). Despite this vision, in the 1950s and 1960s, some students - those considered "noneducable" -continued to be referred to institutions without opportunities for education. It was not until 1967 that all children with disabilities were granted access to schools (SFS 1967:940).

Prior to 1973 in the United States, some students with IDs received educational services in public schools, institutions, or local religious institutions, but school-age students with IDs were not yet guaranteed the right to participate in public schools in their communities. The Rehabilitation Act (1973) outlawed discrimination on the basis of disability in programs that receive federal funding, including public schools, and Section 504 of this law provided some protections for students seeking accommodations to access public school settings. In 1975, the Education for All Handicapped Children Act (EAHCA later the Individuals With Disabilities Education Improvement Act, IDEIA) was passed. Prior to this legislation, approximately one million school-age children with disabilities in the United States did not attend public schools (West, 2000).

\section{Normalization}

In response to the institutionalization people with IDs faced during the 19th and 20th centuries, legislation in Western countries the past 50 years has been more closely aligned with the principle of normalization formulated by Bengt Nirje in the 1960s (Nirje, 2003). The principle is based on eight points that must be met for good support: (a) normal daily rhythm (i.e., regular meals and a daily rhythm that does not deviate from that of nondisabled individuals); (b) normal weekly rhythm (i.e., most people live in one place and have their work or their education in another); (c) normal annual rhythm (i.e., to experience weekends and holidays, get vacations, and travel); (d) normal developmental stages (i.e., the importance of experiencing the different developmental stages of life: childhood, adolescence, adulthood, and old age); (e) have their requirements respected (i.e., the importance of making their own choices and wishes that must be respected); (f) staff of both genders in both care and nursing; ( $g$ ) normal economic standard (i.e., access to normal economic and social security shall apply to all); and (h) normal building standard (i.e., the same standard should apply to people with disabilities as to other community citizens, including better opportunity for integration; Nirje, 2003).

\section{Least Restrictive Environment}

The concept of least restrictive environment (LRE) was introduced in the United States with the passage of the IDEIA in 1975 (EAHCA, 1975). This legislation provided definitions for 13 disability categories, including mental retardation, which would later become intellectual disability. While some argue the IDEIA provided the structure and necessary regulations to ensure access for students with disabilities (Katsiyannis, Yell, \& Bradley, 2001), others argued this legislation created a second, separate system for serving students with disabilities that led to labeling, segregation, and stigma (Ferri \& Connor, 2004). In alignment with Nirje's (2003) normalization principle, the IDEIA uses the term least restrictive environment to describe the mandate that students should be educated with children who do not have disabilities "to the maximum extent appropriate" (IDEIA, 2004). The IDEIA also mandates school districts to provide a continuum of placement options, from those considered "most restrictive" (e.g., hospitals and special education schools) to those considered "least restrictive" (e.g., general education settings)

According to the most recent data, 425000 students in the United States receive special education services under the label of intellectual disability (National Center for Education Statistics [NCES], 2019). Despite a clear preference for the LRE, approximately $76 \%$ of school-age students with IDs in the United States are educated in self-contained special education classrooms on general education campuses for the majority of their school day (Kleinert et al., 2015; NCES, 2019). Although there has been some increase in the number of students with IDs spending $80 \%$ or more of their day in general education since 2000 (from 13\% to 16\%), most of this change occurred from 2000 to 2006, with minimal change in placements among students with IDs from 2006 on (Morningstar, Kurth, \& Johnson, 2017; NCES, 2019). Currently, 50\% of students with IDs spend less than $40 \%$ of their day in general education, $27 \%$ are in general education from $40 \%-79 \%$ of their time, and $16 \%$ spend $80 \%$ or more of their school day in a general education class (NCES, 2019).

The Swedish Education Act (SFS 2010:800) states all children should receive their education by attending compulsory schools. In the Swedish compulsory school system for students ages 6-16, there are four different educational programs (SFS 2010:800): one for compulsory school, one for compulsory schools for students with intellectual disabilities (CSSIDs), one for special schools that teach students with visual impairment or hearing impairment, and one for students of Sami origin. In all four programs, there are common curricular elements fundamental to all students-for example, the school's mission to educate about democracy, the equal value of all humans, and values in line with the content of the Convention on the Rights of the Child (United Nations, 1989). The main differences between the four syllabi are the emphases within each subject, the learning objectives, and the knowledge in which the students are assessed.

According to the latest statistics from the Swedish National Agency for Education (2019), the number of students in CSSIDs is increasing. During the 2018-2019 school year, 10612 students attended CSSIDs, an increase of almost 7\% compared to the previous school year. The largest increase for the 2017-2018 school year was in the "training school" CSSIDs established to meet the needs of students with moderate to severe IDs. In that group, there was an increase of $9 \%$ compared to the previous school year (2016-2017). The training school had 4567 students in the 2017-2018 school year, which is $43 \%$ of all students in CSSIDs. The majority of students in CSSIDs-six out of 10-are boys. There is an inflow of students in the higher grades, and the majority of the students who have a mild ID are switched to a CSSID late in their school career. They often begin in the compulsory school but are offered a placement in the CSSID upon experiencing difficulty achieving the academic expectations in that setting. These students are then identified as having an ID via a medical, psychological, social, and educational assessment.

\section{Inclusive Education}

Although placement data are readily available for each of our countries, physical placement does not adequately address the degree to which students access and benefit from their education. Despite the promises of individualization and support in special education settings, several researchers have established that self-contained settings offer a high level of distraction, fewer opportunities to respond to instructional cues, and a lack of tailored instruction for individual students (Causton-Theoharis, Theoharis, Orsati, \& Cosier, 2011; Kurth, Born, \& Love, 2016). In contrast, general education settings offer increased opportunities to learn, benefit from targeted instruction, and interact with typical peers (Hehir et al., 2016 McDonnell, Thorson, \& McQuivey, 2000; Taub, McCord, \& Ryndak, 2017).

Inclusive education has been defined in many ways, but these definitions consistently describe the critical role of placement in general education settings; support to access the environ- 
ment and curriculum; and accessible, shared experiences and instruction for all students (Skrtic, Sailor, \& Gee, 1996; Olson, Leko, \& Roberts, 2016; McLeskey, Waldron, Spooner, \& Algozzine, 2014). Benefits of inclusive education for students with disabilities include improved literacy, language, and math skills compared to students educated in segregated settings (Buckley, Bird, Sacks, \& Archer, 2006; Hehir et al., 2016; improved social competence (Fisher \& Meyer, 2002); improved communication skills (Ryndak, Ward, Alper, Storch, \& Montgomery, 2010); and improved outcomes related to employment and community involvement as an adult (Wagner, Newman, Cameto, Levine, \& Garza, 2006). Several studies have indicated students without disabilities benefit from inclusive education through positive impacts on academic achievement (Staub \& Peck, 1995), growth in social understandings and empathy (Janney \& Snell, 2006), and greater understanding of differences (Lyon, Blue-Banning, \& McCart, 2014).

In a recent report, the European Agency of Special Needs and Inclusive Education (2018) indicated a link between inclusive education and social inclusion in education, employment, and living conditions; factors that either promote or hinder inclusion include the quality of inclusive practice, social policy, structures and attitudes in society, and events in the life of the individual. The research findings mentioned in the review suggest schooling in the CSSID reduces opportunities for social inclusion in the short term and in the long term. According to the report, there is a correlation between schooling in self-contained settings and poorer study and vocational qualifications, sheltered employment, financial dependence, poorer opportunities for independent living and poorer social network after completing schooling (European Agency of Special Needs and Inclusive Education, 2018). To sum up, the report points to the long-term consequences of teaching students with disabilities in self-contained classrooms or segregated settings, which contribute to inequality and exclusion in society.

\section{Alternative Curriculum}

Although the term alternative curriculum is increasingly aligned with specific educational programs for students with IDs, this practice lacks alignment with the principles of LRE and normalization described in educational policy documents in each country. In this section, we propose common definitions for relevant terms and examine implementation of the alternate curriculum in both policy and practice in each country.

\section{Common Definitions}

Curriculum in Sweden is defined as a government-established policy document learning goals in Grades 3, 6, 9. For students with moderate to severe IDs educated in the self-contained training schools, there are no standards for grading the students, and it is not possible for the student to get a grade. Instead, they receive a written assessment that tells them what knowledge they have gained in relation to learning objectives (SFS 2010:800).

In the United States, the term standard refers to "learning goals for what students should know and be able to do" (National Governor's Association Center for Best Practice, 2010, About the Standards, para. 2). The term curriculum is generally used to refer to what happens in the classroom to meet the learning goals defined by the state. This includes lessons, assignments, and materials teachers use (Oliva, 1982). Although many educators in both special and general education develop their own curricula, the rise of standardized assessments following No Child Left Behind has led to an increase in prepackaged curricula (often in the form of textbooks with teachers manuals providing suggested learning activities and online materials) in general education settings.

For discussion in this paper, we use the term alternate curriculum to refer to expectations for learning established by state/national agencies in each of our countries, expectations for students with IDs that differ from expectations for students without disabilities, and approaches to meeting these expectations. We refer to specific software, workbooks, textbooks, or other resources as curricular materials.

Policy Foundation of Alternate Curricula in the United States and Sweden

In the United States, prior to the reauthorization of the IDEA in 1997, there was no federal requirement that students with significant disabilities be included in large-scale assessments of academic performance, and alternate curricula had not been established on a national level. Following the passage of the No Child Left Behind of 2001 (NCLB, 2002), later replaced by ESSA (2015), all students in the United States must participate in statewide accountability measures, regardless of disability status. These assessments were recently aligned with the CCSS in most states. These standards serve as the basis for the skills and knowledge students are expected to acquire through participation in public education and are used in the development of curricular materials adopted by each state. Due to the continued federal requirement that all students must participate in testing (ESSA, 2015), alternative assessments have now been developed by most states to assess the progress of students with significant support needs for whom IEP teams feel the standardized test is not an accurate measure of their progress.

To align learning objectives with alternate assessments, in 2003, regulations allowed states to set alternate achievement standards. In 2007, an analysis of alternate standards (for the states that had them) found, in comparison to established standards for general education students, alternate achievement standards included no meaningful progression of skills from elementary to high school (Towles-Reeves, Kleinert, \& Muhomba, 2009). With the adoption of the CCSS in 41 states and the District of Columbia, some states and collaboratives have developed a newer set of alternate achievement curricular standards that reduce the complexity of the CCSS while maintaining alignment to essential elements of the standards (Dynamic Learning Maps, 2016; National Center and State Collaborative, 2014). These alternate standards and assessments are meant to form the curriculum learned by students with the "most significant cognitive disabilities" (U.S. Department of Education, 2003, 34 C.F.R. pt. 200), and participation is determined by IEP teams on an individual level. Consistent with the emphasis on individualization throughout the IDEIA, whether a student is held accountable for the alternate or core curricular standards is a separate decision from their educational placement.

In Sweden, the first official curricula for students with severe IDs was established in 1973 and included all students with IDs. Since the 1970s, the CSSID in Sweden has been using this curriculum (SFS 1967:940), but students with ID are not required to participate in nationwide accountability measures. Since there are not any nationwide accountability measures for students with IDs, it is the responsibility of local school authorities to assess students' progress. In 1990, the curriculum was reformed, but just four years later it was replaced with a combined curricula for all four school types in Sweden, the result of a quest for a "school for all" in the Swedish school politics. In 2011, there was a new reform dividing the curricula into four separate programs again (Östlund, 2012, 2015). 
There are different educational paths for students with IDs in Sweden, according to the Swedish Education Act (SFS 2010:800). Each student's guardian/parent has the right to decide which curricula and learning objectives will be used for their child's education. When the students are offered schooling in the CSSIDs, a pedagogical assessment is performed to determine which educational program to recommend for the student. Individual teachers assess whether students have met the standards and learning objectives in the curriculumthere are no standardized tests for students with IDs. Students in general education take national standardized tests in Grades 3, 6, and 9. Getting a grade as a summative assessment is optional for students with mild ID in Grades 6-9. The four pathway options are as follows:

1. Fully included in general education settings following general education curricula,

2. Fully included in general education settings following the CSSID curricula,

3. In a self-contained classroom in a school following the CSSID curricula, or

4. In a special school with its own campus following the CSSID curricula.

\section{Current Practice: Alternate Curricula in the United States and Swe-} den

The entrenchment of alternate curricula as the default standard for students with ID in both US and Sweden in recent years has served to reify the legislative and structural foundation for separate systems of general and special education in each country. Although the separateness of these structures are deep-rooted, there is significant variability in implementation of alternate standards for teaching in the US (Thurlow et al, 2017) while in Sweden, the alternate curriculum is implemented in a relatively uniform manner.

\section{United States}

With the release of the CCSS in 2010 and subsequent adoptions in 41 of the United States, several sets of alternate achievement standards were developed that more closely aligned with general education standards compared to the previous emphasis on functional skills. These included "essential elements" (Dynamic Learning Maps, 2016) and "core content connectors" (National Center and State Collaborative, 2014). Although some guidance on implementation of these alternate standards has been provided in professional conferences and presumably within teacher education programs, it is not clear how these alternate standards align with the variety of alternate assessments implemented by states.

As alternate assessments and achievement standards have been developed, there has been a proliferation of prepackaged curricular materials designed for implementation in self-contained special education settings (Taub et al., 2019). Special education teachers are increasingly encouraged or mandated to use these prepackaged curricular materials that purport alignment with the standards (Taub et al., 2019). One of the largest companies marketing alternate materials, n2y, markets the Unique Learning System (ULS), a curriculum estimated to be used in approximately 60000 classrooms in the United States (n2y, 2019a). Implementation of ULS is mandated in several districts across the United States, including the Los Angeles Unified School District (n2y, 2019b).

\section{United States example: The Los Angeles unified school district}

In the Los Angeles Unified School District in California, beginning in kindergarten (age 5), students who receive special education services are determined to be working toward either the "alternate curriculum" or the "core curriculum" based on an assessment conducted by district staff. Students determined to be working toward the alternate curriculum may be offered a range of placements by the school district. Most often, the offer of placement for students working toward alternate achievement standards is a self-contained special education class comprised of other students with IDs (97\%), although some students (approximately 2\%) are educated in general education classes with support determined by their IEP, and a small number of students attend special education schools (A. Hanreddy, personal correspondence, July 9, 2019). District wide, the school district has implemented the ULS-a mandated, prepackaged curriculum for students with IDs in language arts, math, social studies, and science. The ULS curriculum is used in approximately 860 classrooms with approximately 9,000 students (n2y, 2019b). When students who are working toward alternate achievement standards in the Los Angeles Unified School District are included in general education for $80 \%$ or more of the day, the general curriculum is used as the foundation for instruction, with adaptations to the curriculum provided as needed (Los Angeles Unified School District, 2017).

\section{Sweden}

In Sweden there is only a very small selection of teaching materials adapted for the CSSIDs, and it is the responsibility of every teacher to adapt materials and assessment to suit students with IDs. In a recently released report, the Swedish National Audit Office (2019) criticized the Swedish National Agency for Education and the Agency of Special Needs Education in Sweden for not assisting CSSID teachers with assessment support and in interpreting how standards in the alternate curriculum should be assessed. In total, teachers in primary school subjects have access to materials to support assessment in three of 13 subjects, and these materials have existed for a relatively short time-since 2014. In comparison, teachers in compulsory schools in Sweden have access to assessment support in all subjects. The large difference in the number of assessment materials shows teachers in CSSID have a significantly poorer ability to assess students' knowledge than teachers of the compulsory school.

\section{Swedish example}

Compared to the variability of policies and implementation in the United States, the Swedish system is implemented on a national level. Students with IDs who are not expected to achieve the learning objectives set by the curricula for the compulsory school are most often educated in the CSSID. To get access to education within the CSSID curriculum, a student must have undergone a medical, psychological, social, and educational assessment that clearly shows the student has an ID. This compulsory school program has been adapted for students with IDs and teaches mostly the same subjects as in the regular compulsory school but with its own scope and sequence. Students with mild IDs study subjects such as Swedish language, math, arts, English language, sports, natural sciences, social sciences, home economics, and handicraft. Students with moderate to severe IDs get education in five subject areas: communication, aesthetic activities, perception of reality, everyday activities, and motor skills.

The education in CSSID is organized in various ways in different municipalities. Twenty percent of the students with mild ID are included in general education classes for at least $50 \%$ of their time in school. This number has been constant since the beginning of the 1990s. However, no statistics are collected on how many students with moderate to severe ID are integrated into ordinary school classes. In Swedish research (Östlund, 2015), there are no examples of students with severe to moderate IDs with an alternate curriculum integrated into classes with typically developing students (Swedish Schools Inspectorate, 2016). 


\section{Analysis: Alternate Curricula as a Barrier to Inclusive} Approaches

The establishment of separate learning standards for students with ID in both the US and Sweden has led to several barriers that compound the previously existing separate structures for teaching and learning. These include an emphasis on life skills instead of broader academic skills, reduced access to the content and skills taught in general educaton setting; the implication that a separate setting is required in order to teach the separate curricula; and less preparation to live and work in inclusive settings as an adult.

\section{Life Skills Over Academic Skills}

There is a long tradition of teaching students with IDs functional skills rather than academics in segregated settings in both United States and Sweden (Anderson \& Östlund, 2017; Thompson, Walker, Shogren, \& Wehmeyer, 2018). The National Council on Disability (2018) refers to this tendency toward the status quo as an "organizational tradition" ( $p$. 35). The teaching in the CSSID in Sweden has been criticized since the late 1990s for being too focused on "care" at the expense of students' knowledge development (Swedish National Agency for Education, 2002; Swedish National Audit Office, 2019). The most recent review (Swedish Schools Inspectorate, 2010) showed similar patterns. The audit showed teaching in the audited schools often lacked sufficient knowledge challenges. The review also highlighted deficiencies in teachers' assessment of students' knowledge development. All schools in the survey also lacked compilations and analyses of students' knowledge outcomes in various subjects. Thirty years of research (Arvidsson, 2016; European Agency of Special Needs and Inclusive Education, 2018; Östlund, 2015) and evaluations (Swedish Schools Inspectorate, 2010; Swedish National Agency for Education, 2002) point to barriers that arise from the structure of separate schooling for students with IDs. From a teaching perspective, research points to shortcomings in the expectations of learning for students. Regarding the long-term implications of this model, studies have showed students educated in self-contained settings are less likely to get a job, attend education programs as young adults, and be socially included in society as adults than students without disabilities (Arvidsson, 2018; European Agency of Special Needs and Inclusive Education, 2018).

Similar to criticisms of the Swedish alternate curricula for lacking adequate challenge or analyses of student learning, self-contained classes in the United States have also been criticized for spending too little time on instruction as well as an emphasis on skills taught out of context (Causton-Theoharis et al., 2011; Kurth et al., 2016). As in Sweden, there is a tradition in the United States of prioritizing "life skills" over academic skills (Browder et al., 2004; Timberlake, 2014). For example, the popularity of "task boxes" that contain manipulatives or laminated cards focused on a specific skill (e.g., sorting, sequencing, or counting), often used in self-contained settings, is evidenced by the over 3400 results displayed on Teachers Pay Teachers (2019), a popular site for teachers to share resources with one another despite no available evidence on their effectiveness. This practice, among others, stands in sharp contrast to the rich curricular units that comprise most of the general education core curriculum (Lee, Wehmeyer, Soukup, \& Palmer, 2010; Taub et al., 2017).

\section{Access to the General Education Curriculum}

Access to general education curriculum and access to general education settings are correlated, but not analogous, concepts. Legal mandates in the United States (Every Student Succeeds Act, 2015; IDEIA, 2004) emphasize access to the general education curriculum regardless of the setting where students are educated. These mandates were created to address achievement gaps between students with and without disabilities and are based on the presumption that access to the same curricular expectations and inclusion in accountability systems (i.e., state testing) will ensure teachers hold high expectations for students regardless of disability labels (Lowrey, Drasgow, Renzaglia, \& Chezan, 2007).

The IDEIA (2004) defined general education curriculum as "the same curriculum as for nondisabled children" (34 CFR $\$ 300.320(a)(1)(i)$. According to the same law, students who receive special education services are also entitled to adjustment of the curriculum "to address the unique needs of the child that result from the child's disability and to ensure access of the child to the general curriculum" (34 CFR \$300.39(b)(3)). These adjustments, often referred to as adaptations (Lee et al., 2006), are described in an individual student's individualized education program (IEP). Thus, although students must access the general curriculum, special education law in the United States provides school teams the flexibility needed to promote this access.

Despite an unambiguous definition for general education curriculum in legislation in the United States, there remains disagreement among special and general educators on the enactment of access to the general education curriculum (Dymond, Renzaglia, Gilsin, \& Slagor, 2007). In fact, most special educators appear to interpret this access to include significant adaptation and an emphasis on life skills within the curriculum (Dymond et al., 2007; Timberlake, 2014), while a few place emphasis on both the setting (general education class) and the same materials as students without disabilities (Cosier, Causton-Theoharis, \& Theoharis, 2013). Further, there is evidence special education teachers serving students with IDs are often not provided with the same materials as those used in general education classes (Taub et al., 2019).

Although it might be implied that emphasis on access to the general education curriculum promotes access to general education settings for students with IDs, data on educational placements of these students do not support this assumption (U.S. Department of Education, 2018. Since its initial passage in 1975, in addition to requirements related to general education curriculum, IDEIA (2004) has emphasized access to general education settings. The law states school teams must ensure "access to the general education curriculum in the regular classroom, to the maximum extent possible" (20 U.S.C.\$1400(c)(5)(A)), yet there has not been a marked increase in time spent in general education for students with IDs since the reauthorizations of ESSA and IDEIA.

Sweden has had "a school for all" as an overall education goal for the past 70 years. Everyone who works in a school is expected to prevent discriminatory behavior, and schools must take into account differences in students' abilities and provide appropriate educational support. In the Swedish education policy, there has been a clear inclusive intention since the 1980s; in recent years, the goals of a physically and socially accessible school have also been clarified. In 2014, this perspective was strengthened when lack of accessibility in schools became a basis for discrimination in Swedish legislation. Regardless, this idea has not yet reached far enough to include students with IDs. If students are following the alternate curricula of the CSSIDs and included in general education, the required time on various subjects differs. For example, in CCSIDs, students are expected to have 5 times as many lessons in home economics as students in general education and twice as many lessons in crafts. To meet the mandated hours, these students, then, are required to leave general education to get the right "hours" following the curricula for the CSSID, which becomes an obstacle to 
including the student in general education. Something we noticed in the latest review (Swedish National Audit Office, 2019) is that no national analyses are conducted of students' results within CSSIDs from the National Board of Education. This is noteworthy and is an indication the system of special schools and self-contained classrooms for students with IDs contributes to segregation both in the short and long term.

\section{Separate Curricula, Separate Spaces}

It is evident from the policy and practice foundations described previously that there is a strong connection between segregated learning environments and lower expectations for students with IDs. Beratan (2008) defined institutional ableism as "discriminatory structures and practices, as well as uninterrogated beliefs about disability that are deeply ingrained within educational systems" (p. 338). Given our history of segregation on the basis of perceived ability, it is the responsibility of antiableist educators to view traditional approaches for educating students with IDs through a critical lens. Other authors (Halle \& Dymond, 2008; Jackson, Ryndak, \& Wehmeyer, 2008; Ryndak, Moore, \& Orlando, 2008) have explored whether students with IDs could adequately be taught genera education curriculum while maintaining separate settings and have emphasized the importance of context in accessing the curriculum. That is, emphasis on only the content of the curriculum does not provide full access. Further, by interpreting "access to the general education curriculum" as access to general education content, while allowing students to continue to be educated in separate settings, ignores the intent of inclusive educational practices and serves to strengthen divisions between general and special education.

As access to the general education curriculum for students with IDs is further distorted to become a set of alternate learning expectations, learning materials and expectations in self-contained settings remain substantially different from those in general education. Thus, a structure is created and reified in which "alternate" standards are the responsibility of the special educator. As such, time spent in general education may be viewed as a "waste" or an interference with the special educators' time and ability to address the learning expectations they are responsible for teaching.

\section{Long-Term Impacts of Alternative Curricula}

Given the goals of inclusive education are stated by many to be greater levels of community participation, employment, and self-determination in adulthood (Ryndak et al., 2010; Slee 2011), it is reasonable to examine the long-term impact of alternate curricula and associated separate schooling. As illus trated by the shared histories of marginalization and exclusion in the United States and Sweden, students with IDs have long been subjected to segregation and lowered expectations in school settings. The outcomes for adult life following an education on the alternate curricula in self-contained settings indicate adults with IDs continue to follow the trajectory of dependence and isolation established throughout their schooling experiences (Bouck, 2012; Ryndak et al., 2010).

In a large-scale Swedish research study, Arvidsson (2016) followed up on 12,269 students with IDs to gain knowledge of what kind of postschool occupations young adults with IDs had. Results from the study showed $47 \%$ participated in daily activities; $22.4 \%$ were employed, most of them with some type of wage subsidy; $6.6 \%$ participated in various forms of education programs; and a large group (24\%) was described as being "elsewhere" (not in any of the other three types of occupations; Arvidsson, 2016). Arvidsson (2016) stated the large number of young adults with IDs having an occupation "elsewhere" was unexpected. From an inclusive education perspective, these results indicate the CSSID prepares students for a life in the margins rather than preparing them for a life in an included society. According to the Swedish welfare system, adults with IDs are entitled to participate in daily activities, so the welfare program helps them gain employment after school. For many, the only option is for students to transfer from the CSSID to "daily activity," which is a service for working-age individuals with IDs who are not gainfully employed or studying. By providing only segregated options, the welfare system contributes to a structural segregation of students with IDs.

\section{Alternate Curricula and Teacher Preparation}

Reliance on seperate curricula in separate spaces for students with ID has led to minimal preparation or expectation among general education teachers to teach these students. With special educators in short supply, this means that many students with intellectual disabilities are taught by teachers who are less qualified than their general education peers.

\section{General education teachers}

The establishment of separate learning objectives and separate materials for students with IDs, combined with the lack of trained special education teachers, may lead to reluctance on the part of general education teachers to include students who they do not feel prepared to teach (Swedish National Agency for Education, 2019). The Swedish school system has a 150-year history of organizing education in dual systems-a system for students in general education and a separate system for students with IDs. Although general education teachers have the ability to teach students with IDs in an inclusive setting, they often question their ability to differentiate their own teaching. Instead, they may recommend the special student be placed in a special setting, with a special curriculum with a special teacher.

General educators in both the United States and Sweden currently receive minimal training and information on special education and IDs. Although teacher training programs vary significantly, general educators in the United States report feeling unprepared to teach learners with disabilities (Blanton, Pugach, \& Florian, 2011). It is common in both countries for teacher preparation programs to include only one course on special education for general education teacher candidates, and this course may emphasize characteristics of disability labels rather than strategies for curricular access (Blanton et al., 2011). Since most students with IDs are currently not taught in general education settings (Kleinert et al., 2015; NCES, 2019), they may be considered only peripherally in such courses. When teacher credential programs do not adequately prepare candidates to meet the needs of students with IDs, there is a risk these teachers will advocate for segregated settings where students with IDs can receive assistance from a special teacher who they perceive as more knowledgeable about the separate curricular standards and materials taught in those spaces.

\section{Special education teachers}

A shortage of special educators in Sweden and the United States has resulted in limited access to quality instruction in self-contained settings. In Sweden, there is a significant shortage of special educators serving students with IDs. Only $20 \%$ of special educators have the correct credential, and some have no credential at all. While the shortage of special educators in the United States is not as dire as in Sweden, 49 states report a shortage of special educators, and the caseloads of existing special educators continues to rise (Samuels \& Harwin, 2018).

When students are taught by unqualified staff in settings lacking accountability, it is inevitable students' access to equitable learning conditions will be limited. The Swedish Schools Inspectorate (2010) examined teaching in 28 schools with self-contained classrooms following the CSSID curriculum and found teachers often neglected active reading instruction for 
the older students and prioritized self-care and a good emotional climate in the school instead. Many teachers did not take into account the strengths and needs of each student, and the tasks for many students lacked adequate challenge. In higher grades, it was common for teachers to read aloud to students. It was rare, however, for teachers to support students' listening by discussing material and engaging in dialogue on the content of texts. In schools, students were allowed to borrow books based on their own interests, but they were rarely given opportunities to reflect on the reading with a peer or teacher. This study reflects the fact that school authorities have long neglected the teaching of students with IDs. For many years, there were no guidelines for special education credentials, and it was not until 2012 that specific training for teachers with specialization in IDs was established. It is also a consequence of the fact that CSSIDs have, for a long time, lacked and still lack state assessment support to helps special teachers assess students' knowledge development.

\section{Implications}

There are many similarities between the US and Sweden in both policies and practices related to alternate curricula that have served to maintain segregated education. In Sweden, there is a nationally mandated alternate set of learning expectations for students with IDs. In the United States, there is a nationally recognized set of learning goals for all students (Common Core), adopted in 41 states, and a national mandate for students with disabilities to make progress toward the core curriculum (ESSA, 2015; IDEIA, 2004). Despite these differences in policy, the practical lives of students with IDs in school remain remarkably similar. Most students with IDs are educated in self-contained settings, and most students are taught using materials and approaches that differ markedly from those used in general education, with drastically different learning goals established by teachers. Unsurprisingly, outcomes for these students are also similar in our countries. Adults with IDs in both countries experience high rates of unemployment and thus poverty and reliance on governmental supports (Arvidsson, 2016; Bouck, 2012; Wagner et al., 2006).

We have established that the struggle to achieve access to both general education curriculum and general education settings is rooted in a history of entrenched ableism. This ableist structure promotes the notion of alternative learning goals and spaces in the spirit of care and individualization, despite strong evidence this approach is not only inherently inequitable but leads to poor outcomes (Anderson \& Östlund, 2017; Bouck, 2012; Causton-Theoharis et al., 2011; Cosier et al., 2013). Alternative curricula, therefore, should be viewed with suspicion and as a mechanism of segregation. As an education community, it is time to revisit this issue in teacher preparation, instructional approaches, and policy as we work towards broader ownership, raised expectations, improved access, and enhanced long term outcomes for students with ID.

\section{Educator Preparation}

General education teachers in the United States and Sweden often feel unprepared to provide students with IDs meaningful access to the general education curriculum (Anderson \& Östlund, 2017; Da Fonte \& Barton-Arwood, 2017). To promote meaningful access to all elements of the general education curriculum for students with IDs, these teachers must feel well prepared to foster learning environments that are welcoming and accessible to all students. Rather than limit instruction related to disability to one university course, preparation to foster inclusive learning environments and effectively teach students with IDs (and other disabilities) can be embedded throughout candidates' training. For example, when studying pedagogy for mathematics instruction, candidates can learn to incorporate multiple access points and to adjust instruction to address foundational skills while also introducing new concepts. Similarly, programs preparing special educators must ensure their graduates are prepared with the skills to teach in inclusive (rather than segregated) settings and to individualize instruction in these settings while ensuring access to the curriculum. In the United States, some states have started to identify increased areas of overlap between what general and special educators must know and be able to do by the end of their credential programs, and some credential programs have started to offer concurrent programs for earning both a general and special education credential (Reese, Richards-Tutor, Hansuvadha, Pavri, \& Xu, 2018; Young, 2008).

Students with IDs often receive at least some support from a paraprofessional during their school day, and some students receive all or most of their instruction from a paraprofessional (Giangreco, Suter, \& Hurley, 2013; Östlund, 2012). Despite the important role these individuals play in a school setting, they often receive minimal training in preparation for their role (Giangreco, Broer, \& Suter, 2011), leading to a host of unintended negative consequences (Giangreco, 2010). By expanding the role of special educators in general education settings through coteaching and individualized supports, individual students will become less reliant on the support of paraprofessionals as proxies for special educators. In addition, training specific to the role of a paraprofessional in supporting access to the general education curriculum for all students will support raised expectations as well as engaged and purposeful learning for students with IDs.

\section{Pedagogy}

General education curricular reforms in recent years have played a role in moving instruction from rote practice to an emphasis on developing conceptual understandings, using language to articulate learning, and identifying connections across the curriculum (Alberti, 2012; Swedish National Agency for Education, 2018; Yilmaz \& Topal, 2014). These pedagogical practices stand in contrast to those in self-contained settings for students with IDs in which the expansion of "alternate curriculum" has maintained focus on concrete understandings, isolated skills, and self-care tasks (Östlund, 2015; Taub et al., 2019. This division between the emphases of learning goals and teaching materials for each population of students solidifies the misconception of special education as a practice incongruous with general education settings. Pedagogical practices that promote access to general education settings for students with IDs include universal design for learning (UDL), project-based learning (PBL), embedded instruction, culturally responsive teaching, and formative assessment strategies. Each of these practices can be considered as critical components in school change efforts to promote the inclusion of students with IDs.

Universal design for learning. To promote meaningful access to general education settings and curriculum, instruction in these settings must shift to models of accessible instruction that consider the variety of learning strengths and needs among all school-age students. Universal design for learning is a set of principles that draws upon the basic learning processes of recognition, expression, and motivation, and incorporates student voice and choice into instructional design (Center for Applied Special Technology, 2019). The guidelines emphasizing multiple means of representation, expression, and engagement are designed for implementation in general education settings, and training related to these principles have become more common in recent years (Jiménez, Graf, \& Rose, 2007; Scott, Thoma, Puglia, Temple, \& Aguilar, 2017). Although UDL is already beginning to benefit students with high incidence disabilities (Capp, 2017; Katz, 2013), it will be critical for school teams to 
ensure UDL implementation occurs in tandem with increased inclusion of students with IDs, and that instruction is designed with consideration of the needs of these students.

Project-based learning. To ensure inclusive pedagogy in general education while addressing the wide range of skills students need in the 21st century, we must shift our traditional instructional model to one in which student learning begins with the end in mind. For example, PBL is an instructional model in which students work to develop a solution to a real-world problem (Bell, 2010). By shifting our focus to project-based and other inquiry-focused models, students naturally incorporate multiple disciplines and see the interconnections between subjects traditionally taught in an isolated manner. The applied nature of these instructional approaches supports both critical thinking and "real-world" understandings (Mkrttchian, 2018). When students work from a problem-solving approach, they can leverage strengths more effectively than models that rely on isolated skills.

Embedded instruction. Although many special education approaches continue to be based on a model of remediation in an effort to help students with disabilities "catch up" to their "typical" peers, this approach is often framed in terms of students' perceived deficits. For students with IDs, using a remediation model carries the potential of playing a neverending game of catch up. Instead, analyzing the "mismatches" between an individual student's current skills and the skills needed to participate in a given learning activity allows school teams to take action to promote greater access. Using this ecological approach, mismatches can be remediated by mak ing changes to the activity (e.g., providing many ways for students to demonstrate their learning), curricular adaptations, or individualized embedded instruction (Downing, 2010; Johnson, McDonnell, Holzwarth, \& Hunter, 2004).

Culturally responsive teaching. As classrooms in both United States and Sweden serve students from increasingly diverse socioeconomic and cultural backgrounds and whose primary home language is not English, we must further examine pedagogy with attention toward culturally and linguistically diverse (CLD) students with IDs. These students appear to face more challenges than typical CLD peers or peers with IDs who are not CLD related to access to general education curriculum, access to services to address their unique needs, and partnerships with families (Mueller, Millian, \& Lopez, 2009; Mueller, Singer, \& Carranza, 2006; Rivera et al., 2016). Rivera et al. (2016) identified a framework for aligning existing evidence-based practices for teaching CLD-typical students with the unique needs of CLD second language learners with IDs. This model builds upon previous approaches that emphasize a safe learning environment, primary language support, and the use of systematic instruction (Sanford, Brown, \& Turner, 2012; Sobul, 1995) but places additional emphasis on UDL, the integration of culture, multiple opportunities to respond, technology, and self-determination (Rivera et al., 2016). Although this model was proposed to meet the unique needs of CLD students with IDs, the additional emphases are consistent with the needs of all learners in diverse general education classrooms and are consistent with evidence-based practices for inclusive teaching approaches in general education.

Formative assessment strategies. Current attempts at identifying a uniform set of simplified expectations in the form of an alternate curriculum fail to account for the vast heterogeneity of students with IDs. Meaningful access to general education curricula for students with IDs will require teachers to recognize the diversity of students by tailoring instruction and learning goals on an individual level. To adequately gauge students' skills and understanding of material, teachers must become skillful in their use of authentic data to measure student performance. Formative assessment refers to the various ways teachers gather information on student learning throughout the learning process to provide feedback and adjust and plan instruction. The strategic use and analysis of formative assessment approaches is a well-supported practice (Bell \& Cowie, 2001; Hattie, 2012) that can provide a "snapshot" of the learning strengths and needs of students relative to clearly identified objectives. For students with IDs, formative assessments consistent with UDL provide many ways for students to express their understanding of "big ideas" or target skills in a curricular unit. For example, students might demonstrate understanding of key events in a piece of children's literature through comments in a small group discussion, illustrations on an art project, use of collage or selecting pictures, or through written responses.

\section{Policy}

Given our history of segregation of students with IDs, without structural changes, progress toward improved access to general education curricula and settings will not be sustained over time. As previously established, the current general and special education systems in both the United States and Sweden are deeply entrenched and will continue as such unless educators and families begin to question the validity of the current approach. We have established in this paper that alternative curricula, materials, or standards for any population of students on the basis of a disability label serves to maintain segregation and institutionalized ableism. Rather, we must affirm the value of inclusive educational approaches and shift the conversation from one about placement to a dialogue on the instructional practices that make an environment inclusive. From a policy perspective, recommendations aligned with inclusive practices are already well established and being implemented internationally, although infrequently (Booth \& Ainscow, 2011; Choi \& Park, 2018; Shogren, McCart, Lyon, \& Sailor, 2015). International policy resources such as the UN Convention on the Rights of Persons With Disabilities (United Nations General Assembly, 2007), the WHO's (2011) World Report on Disability, and the International Classification of Functioning (WHO, 2001) provide frameworks for examining access in terms of civil rights. On a more practical level, the Index for Inclusion (Booth \& Ainscow, 2011), a tool for self-evaluation of evidence-based practices in inclusive education, has been translated and adapted for use in many countries. Aligned with these recommendations, we propose the following:

- Affirm the general education class as the default setting for all students and develop accountability measures to evaluate implementation. This presumes students do not need to "earn" the right to be taught in a general education class and will set the expectation that general education curriculum will be accessible. Despite the fact this policy is already in place in the United States, students with IDs remain largely segregated.

- Expand expectations for general and special educator training programs to emphasize inclusive pedagogy across the curriculum. Rather than one isolated class on special education for general educators, strategies for making curriculum accessible must be embedded throughout the program. Similarly, special educator programs must not assume graduates will teach in self-contained classes; rather, programs should prepare them to coteach, adapt curriculum, and provide embedded instruction to students with a variety of support needs.

- Establish the general education curriculum as the default curriculum for all students. All students must benefit from the common set of concepts and skills established in the curriculum. This curriculum must lend itself to the principles of UDL and PBL and thus allow many opportunities for students to understand curricular content and express their knowledge and skills. Curricular expectations can be paired with individualized 
learning goals to allow for tailored and embedded instruction for students who need additional support.

- Provide structures within school systems that support collaboration among teachers and allow the time needed to work together to proactively plan for students and adjust instruction using formative assessments. These structures include planning time counted as part of a teacher's work day and coordinated schedules that allow general and special educators to work together.

- Develop systems to support coteaching approaches in which special and general educators deliver instruction together on a regular basis to their shared students. These systems must include teachers of students with IDs and must ensure parity is maintained between teachers. One teacher is not the "helper" while the other is the "leader." Rather, both are seen as having equal status, and both are responsible for the learning of all students.

- Use accountability measures of teachers and schools that focus on qualities of inclusive teaching and progress for all students in the curriculum. Although in the United States, all students are now included in standardized assessments, this is not the case in Sweden. Further, evaluations of teachers and schools rarely consider evidence-based practices related to inclusive education. To ensure systematic implementation of inclusive approaches, these practices must be included in teacher accountability systems.

\section{Conclusion}

In this concept paper, we have established that despite some unique policies and practices in the United States and Sweden, our two countries share a history of segregation and exclusion, which is further maintained by the separation of general and special education systems. Despite national policies espousing an emphasis on access for "all" students, through our cross-cultural examination of systemic barriers to inclusion, we have noted an international trend toward exclusive mindsets and practices related to curriculum access for students with IDs. The use of separate, lowered, or drastically simplified learning objectives, practices, and materials for students with IDs further reifies entrenched systems of segregation. These alternate curricular expectations have resulted in inequitable access to instruction and opportunity in each country and have resulted in poor outcomes among adults with IDs. Despite efforts by advocates for inclusive practices around the world, many countries maintain separate and exclusive systems for the education of students with disabilities. As this is an international issue, efforts to address these ableist structures must take place internationally. Dialogue and cross-cultural work, the enactment of international principles for disability equity (e.g., the UN Convention on the Rights of Persons With Disabilities) at the policy level, and the translation of these principles to practice at the regional and local levels will be essential in advocacy for access and inclusion. Coordinated changes must occur in the areas of educator preparation, pedagogy, and policy to support a shift toward substantive access to general education settings and curriculum for all students as the default rather than the exception.

\section{References}

Alberti, S. (2012). Making the shifts (Common Core State Standards). Educational Leadership, 70(4), 24-27. Retrieved from http://www.ascd.org/publications/ educational-leadership/dec12/vol70/num04/Making-the-Shifts.aspx
Anderson, L., \& Östlund, D. (2017). Assessments for learning in Grades 1-9 in a special school for students with intellectual disability in Sweden. Problems of Education in the 21st Century, 75, 508-524. Retrieved from http://muep.mau.se/handle/2043/24232

Andriichuk, N. (2017). Historical background of inclusive education development in the Nordic countries. Journal of Vasyl Stefanyk Precarpathian National University, 4, 97-104. doi:10.15330/jpnu.4.1.97-104

Arvidsson, J. (2016). Sysselsättning och social rättvisa: En Nationell Registerstudie om 12,269 unga vuxna med intellektuell funktionsnedsättning [Post-school occupation and social justice: A National Registry study about 12,269 young adults with intellectual disability]. Doctoral dissertation, Halmstad University.

Barow, T. (2009). Kein Platz im Volksheim?: Die "Schwachsinnigenfürsorge" in Schweden 1916-1945. Bad Heilbrunn, Germany: Klinkhardt.

Bell, B., \& Cowie, B. (2001). The characteristics of formative assessment in science education. Science Education, 85, 536-553. doi:10.1002/sce.1022

Bell, S. (2010). Project-based learning for the 21st century: Skills for the future. The Clearing House: A Journal of Educational Strategies, Issues and Ideas, 83, 39-43. doi:10.1080/00098650903505415

Beratan, G. (2008). The song remains the same: Transposition and the disproportionate representation of minority students in special education. Race Ethnicity and Education, 11, 337-354. doi:10.1080/13613320802478820

Blanton, L. P., Pugach, M. C., \& Florian, L. (2011). Preparing general educators to improve outcomes for students with disabilities. Retreived from the American Association of Colleges of Teacher Education and National Council for Learning Disabilities website: http:// www.aacte.org

Booth, T., \& Ainscow, M. (2011). Index for inclusion: Developing learning and participation in schools (3rd ed.). Bristol, England: Centre for Studies on Inclusive Education.

Bouck, E. C. (2012). Secondary students with moderate/severe intellectual disability: Considerations of curriculum and post-school outcomes from the National Longitudinal Transition Study-2. Journal of Intellectual Disability Research, 56, 1175-1186. doi:10.1111/ j.1365-2788.2011.01517.x

Brantlinger, E. (1995). Sterilization of people with mental disabilities issues, perspectives, and cases. Westport, CT: Auburn House.

Browder, D., Flowers, C., Ahlgrim-Delzell, L., Karvonen, M., Spooner, F., \& Algozzine, R. (2004). The alignment of alternate assessment content with academic and functional curricula. The Journal of Special Education, $37(4), 211-223$.

Buckley, S., Bird, G., Sacks, B., \& Archer, T. (2006). A comparison of mainstream and special education for teenagers with Down Syndrome: Implications for parents and teachers. Down Syndrome Research and Practice, 9(3), 54-67. doi:10.3104/reports.295 
Capp, M. (2017). The effectiveness of universal design for learning: A meta-analysis of literature between 2013 and 2016. International Journal of Inclusive Education 21, 791-807. doi:10.1080/13603116.2017.1325074

Carey, A. (2009). On the margins of citizenship: Intellectual disability and civil rights in twentieth-century America. Philadelphia, PA: Temple University Press.

Carnovali, S. (2017). The right to inclusive education of persons with disabilities in Italy. Reflections and perspectives. Athens Journal of Education, 4, 315-326. doi:10.30958/ aje.4-4-1

Causton-Theoharis, J., Theoharis, G., Orsati, F., \& Cosier, M. (2011). Does self-contained special education delive on its promises? A critical inquiry into research and practice. Journal of Special Education Leadership, 24(2), 61-78. Retrieved from http://www.casecec.org/resources/jsel.asp

Center for Applied Special Technology. (2019). About universal design for learning. Retrieved http://www.cast.org/ourwork/about-udl.html

Choi, H., \& Park, S. (2018). Teachers' evaluation of inclusive education practices in elementary schools at Seoul: Using the quality indicators of elementary inclusive education. Korean Journal of Special Education, 53(2), 23-52.

Cosier, M., Causton-Theoharis, J., \& Theoharis, G. (2013). Does access matter? Time in general education and achievement for students with disabilities. Remedial and Special Education, 34, 323-332. doi:10.1177/0741932513485448

Da Fonte, M., \& Barton-Arwood, S. (2017). Collaboration of general and special education teachers: Perspectives and strategies. Intervention in School and Clinic, 53, 99106. doi:10.1177/1053451217693370

Downing, J. (2010). Academic instruction for students with moderate and severe intellectual disabilities in inclusive classrooms. Thousand Oaks, CA: Corwin Press.

Dymond, S. K., Renzaglia, A., Gilson, C. L., \& Slagor, M. T. (2007). Defining access to the general curriculum for high school students with significant cognitive disabilities. Research and Practice for Persons With Severe Disabilities, 32, 1-15. doi:10.2511/rpsd.32.1.1

Dynamic Learning Maps. (2016). What is a learning map model? Retrieved from https://dynamiclearningmaps.org/ about/model\#essential-elements

Education of All Handicapped Children Act (EAHCA) of 1975, Pub. L. No. 94-142, 20 U.S.C.

European Agency for Special Needs and Inclusive Education. (2018). Evidence of the link between inclusive education and social inclusion: A review of the literature. Retrieved from https://www.european-agency.org/resources/publications/evidence-literature-review

Every Student Succeeds Act. (2015). PL 114-95, 114 U.S.C.

Ferri, B., \& Connor, D. (2004). Special education and the subverting of Brown. Journal of Gender, Race, and Justice, 8(1), 57-74. Retrieved from https://jgrj.law.uiowa.edu/

Fisher, M., \& Meyer, L. (2002). Development and social competence after two years for students enrolled in inclusive and self-contained educational programs. Research and Practice for Persons With Severe Disabilities, 27, 165174. doi:10.2511/rpsd.27.3.165
Giangreco, M. (2010). One-to-one paraprofessionals for students with disabilities in inclusive classrooms: Is conventional wisdom wrong? Intellectual and Developmental Disabilities, 48(1), 1-13. doi:10.1352/19349556-48.1.1

Giangreco, M., Broer, S., \& Suter, J. (2011). Guidelines for selecting alternatives to overreliance on paraprofessionals: Field-testing in inclusion-oriented schools. Remedial and Special Education, 32, 22-38. doi:10.1177/0741932509355951

Giangreco, M., Suter, J., \& Hurley, S. (2013). Revisiting personnel utilization in inclusion-oriented schools. Journal of Special Education, 47, 121-132. doi:10.1177/0022466911419015

Grim, A. (2015). Sitting in for disability rights: The section 504 protests of the 1970s [Web log post]. Retrieved from the National Museum of American History website: https://americanhistory.si.edu/blog/sitting-disability-rights-section-504-protests-1970s

Halle, J. W., \& Dymond, S. K. (2008). Inclusive education: A necessary prerequisite to accessing the general curriculum? Research and Practice for Persons With Severe Disabilities, 33/34, 196-198. doi:10.2511/rpsd.33.4.196

Hattie, J. (2012). Visible learning for teachers: Maximizing impact on learning. New York, NY: Routledge.

Hehir, T., Grindal, T., Freeman, B., Lamoreau, R., Borquaye, Y., Burke, S. (2016). A summary of the evidence on inclusive education. Cambridge, MA: Abt Associates. Retrieved online at https://alana.org.br/wp-content/ uploads/2016/12/A_Summary_of the evidence_on inclusive_education.pdf

Individuals With Disabilities Education Improvement Act (IDEIA) of 2004, PL 108-446, 20 U.S.C.

Jackson, L., Ryndak, D. L., \& Wehmeyer, M. L. (2008). The dynamic relationship between context, curriculum, and student learning: A case for inclusive education as a research-based practice. Research and Practice for Persons With Severe Disabilities, 33-34, 175-195. doi:10.2511/rpsd.33.4.175

Janney, R., \& Snell, M. (2006). Social relationships and peer support (2nd ed.). Baltimore, MD: Paul H. Brookes.

Jiménez, T. C., Graf, V. L., \& Rose, E. (2007). Gaining access to general education: The promise of universal design for learning. Issues in Teacher Education, 16(2), 41-54. Retrieved from https://files.eric.ed.gov/fulltext/EJ796250. pdf

Johnson, J., McDonnell, J., Holzwarth, V., \& Hunter, K. (2004). The efficacy of embedded instruction for students with developmental disabilities enrolled in general education classes. Journal of Positive Behavior Interventions, 6, 214-227. doi:10.1177/10983007040060040301

Katsiyannis, A., Yell, M., \& Bradley, R. (2001). Reflections on the 25th anniversary of the Individuals With Disabilities Education Act. Remedial and Special Education, 22, 324334. doi:10.1177/074193250102200602

Katz, J. (2013). The three block model of universal design for learning (UDL): Engaging students in inclusive education. Canadian Journal of Education, 36, 153194. Retrieved from https://files.eric.ed.gov/fulltext/ EJ1008728.pdf 
Keith, H., \& Keith, K. D. (2013). Intellectual disability: Ethics, dehumanization, and a new moral community. Chichester, England: Wiley-Blackwell.

Kleinert, H., Towles-Reeves, E., Quenemoen, R., Thurlow, M., Fluegge, L., Weseman, L., \& Kerbel, A. (2015). Where students with the most significant cognitive disabilities are taught: Implications for general curriculum access. Exceptional Children, 81, 312-328. doi:10.1177/0014402914563697

Kurth, J., Born, K., \& Love, H. (2016). Ecobehavioral characteristics of self-contained high school classrooms for students with severe cognitive disability. Research and Practice for Persons With Severe Disabilities, 41, 227-243. doi:10.1177/1540796916661492

Laughlin, H. (2004). The eugenical sterilization of the feeble-minded. In S. Noll \& J. W. Trent (Eds), Mental retardation in America: A historical reader (History of Disability Series, pp. 225-231). New York: New York University Press.

Lee, S.-H., Amos, B. A, Gragoudas, S., Lee, Y., Shogren, K. A., Theoharis, R., \& Wehmeyer, M. L. (2006). Curriculum augmentation and adaptation strategies to promote access to the general curriculum for students with intellectual and developmental disabilities. Education and Training in Developmental Disabilities, 41, 199-212. Retrieved from the Council for Exceptional Children website: http://daddcec.org/

Lee, S.-H., Wehmeyer, M. L., Soukup, J. H., \& Palmer, S. B. (2010). Impact of curriculum modifications on access to the general education curriculum for students with disabilities. Exceptional Children, 76, 213-233. doi:10.1177/001440291007600205

Los Angeles Unified School District. (2017). Determining the appropriate educational placement for students with disabilities in the least restrictive environment (LRE). Retrieved from https://achieve.lausd.net/

Lowrey, K., Drasgow, E., Renzaglia, A., \& Chezan, L. (2007). Impact of alternate assessment on curricula for students with severe disabilities: Purpose driven or process driven? Assessment for Effective Intervention, 32, 244253. doi:10.1177/15345084070320040601

Lyon, K. J., Blue-Banning, M., \& McCart, A. B. (2014). Lessons from the field. Lawrence, KS: National Center on Schoolwide Inclusive School Reform: The SWIFT Center.

McClammy, W. (2017, March 21). Not special needs [Public service announcement]. Retrieved from http://www.notspecialneeds.com

McDonnell, J., Thorson, N., \& Mcquivey, C. (2000). Comparison of the instructional contexts of students with severe disabilities and their peers in general education classes. Research and Practice for Persons With Severe Disabilities, 25, 54-58. doi:10.2511/rpsd.25.1.54

McLeskey, J., Waldron, N., Spooner, F., \& Algozzine, B. (2014). Handbook of effective inclusive schools. New York, NY: Routledge.

Mkrttchian, V. (2018). Project-based learning for students with intellectual disabilities. In P. L. Epler (Ed.), Instructional strategies in general education and putting the Individuals With Disabilities Act (IDEA) into practice (pp. 196-221). doi:10.4018/978-1-5225-3111-1.ch007
Morningstar, M., Kurth, J., \& Johnson, P. (2017). Examining national trends in educational placements for students with significant disabilities. Remedial and Special Education, 38(1), 3-12.

Mueller, T. G., Milian, M., \& Lopez, M. I. (2009). Latina mothers' views of a parent-to-parent support group in the special education system. Research and Practice for Persons With Severe Disabilities, 34, 113-122. doi:10.2511/ rpsd.34.3-4.113

Mueller, T. G., Singer, G., \& Carranza, F. (2006). A national survey of the educational planning and language instruction practices for students with moderate to severe disabilities who are English language learners. Research and Practice for Persons With Severe Disabilities, 31, 242-254. doi:10.1177/154079690603100304

n2y. (2019a). A total solution for education. Retrieved from https://www.n2y.com/total-solution/

n2y. (2019b). Los Angeles Unified School District [Case study]. Retrieved from https://www.n2y.com/research-and-results/los-angeles-usd-success-with-unique-learningsystem/

National Center and State Collaborative. (2014). Core content connectors. Retrieved from https://wiki.ncscpartners. org/index.php/Core_Content_Connectors

National Center for Educational Statistics (NCES). (2019). Inclusion of students with disabilities. Retrieved from https:// nces.ed.gov/fastfacts/display. .asp?id=59

National Council on Disability. (2018). The segregation of students with disabilities. Retrieved from https://ncd.gov/ sites/default/files/NCD_Segregation-SWD_508.pdf

National Governors Association Center for Best Practices, Council of Chief State School Officers. (2010). Common Core State Standards for English language arts \& literacy in history/social studies, science, and technical subjects. Washington, DC: Author. Retrieved from http://www. corestandards.org/the-standards

Nirje, B. (2003). Normaliseringsprincipen [The principle of normalization]. Lund, Sweden: Studentlitteratur.

No Child Left Behind Act of 2001, P.L. 107-110, 20 U.S.C. § 6319 (2002).

Noll, S., \& Trent, J. (2004). Mental retardation in America: A historical reader (History of Disability Series). New York: New York University Press.

Oliva, P. F. (1982). Developing the curriculum. Boston, MA: Little Brown.

Olson, A., Leko, M., \& Roberts, C. (2016). Providing students with severe disabilities access to the general education curriculum. Research and Practice for Persons With Severe Disabilities, 41, 143-157. doi:10.1177/1540796916651975

Östlund, D. (2012). The contextual conditions for participation, educational practice in five special schools (Unpublished doctoral dissertation, Malmö University, Sweden).

Östlund, D. (2015). Students with profound and multiple disabilities in education in Sweden: teaching organisation and modes of student participation. Research and Practice in Intellectual and Developmental Disabilities, 2, 148164. doi:10.1080/23297018.2015.1085327 
Pelka, F. (2012). What we have done: An oral history of the disability rights movement. Amherst: University of Massachusetts Press.

Reese, L., Richards-Tutor, C., Hansuvadha, N., Pavri, S., \& Xu, S. (2018). Teachers for inclusive, diverse urban settings. Issues in Teacher Education, 27(1), 17-27. Retrieved from https://files.eric.ed.gov/fulltext/EJ1174905.pdf

Rivera, C., Jiménez, B., Baker, J., Spies, T., Mims, P., \& Ginevra, C. (2016). A culturally and linguistically responsive framework for improving academic and postsecondary outcomes of students with moderate or severe intellectual disability. Physical Disabilities: Education and Related Services, 35(2), 23-48. Retrieved from https:// files.eric.ed.gov/fulltext/EJ1125251.pdf

Ryndak, D. L., Moore, M. A., \& Orlando, A. (2008). Access to the general curriculum: The mandate and role of context in research-based practice for students with extensive support needs. Research and Practice for Persons With Severe Disabilities, 33, 199-213. doi:10.2511/ rpsd.33.4.199

Ryndak, D. L., Ward, T., Alper, S., Storch, J., \& Montgomery, J. (2010). Long-term outcomes of services in inclusive and self-contained settings for siblings with comparable significant disabilities. Education and Training in $\mathrm{Au}$ tism and Developmental Disabilities, 45, 38-53. Retrieved from the Council on Exceptional Children website: http://daddcec.org/

Samuels, C., \& Harwin, A. (2018, December 5). Shortage of special educators adds to classroom pressures. Education Week. Retrieved from https://www.edweek.org/ ew/articles/2018/12/05/shortage-of-special-educators-adds-to-classroom.html

Sanford, A., Brown, J., \& Turner, M. (2012). Enhancing instruc tion for English learners in response to intervention systems: The PLUSS model. Multiple Voices for Ethnically Diverse Exceptional Learners, 13, 56-70. Retrieved from https://pdxscholar.library.pdx.edu/edu_fac/85/

Scott, L., Thoma, C., Puglia, L., Temple, P., \& D’Aguilar, A. (2017). Implementing a UDL framework: A study of current personnel preparation practices. Intellectual and Developmental Disabilities, 55, 25-36. doi:10.1352/19349556-55.1.25

SFS 1967:940. (1967). Lagen angående omsorger om vissa psykiskt utvecklingsstörda [Law on care for some groups of people with intellectual disability].

SFS 2010:800: Skollag [Education Act]. Accessed 3 December 2019. https://www.riksdagen.se/sv/dokument-lagar/dokument/svensk-forfattningssamling/ skollag-2010800_sfs-2010-800

Shogren, K., Luckasson, R., \& Schalock, R. (2014). The definition of "context" and its application in the field of intellectual disability. Journal of Policy and Practice in Intellectual Disabilities, 11, 109-116. doi:10.1111/jppi.12077

Shogren, K., McCart, A., Lyon, K., \& Sailor, W. (2015). All means all: Building knowledge for inclusive schoolwide transformation. Research and Practice for Persons With Severe Disabilities, 40, 173-191. doi:10.1177/1540796915586191
Shogren, K., Wehmeyer, M. L., Seo, H., Thompson, J., Schalock, R., Hughes, C., \& Palmer, S. (2017). Examining the reliability and validity of the Supports Intensity Scale-Children's Version in children with autism and intellectual disability. Focus on Autism and Other Developmental Disabilities, 32, 293-304. doi:10.1177/1088357615625060

Skrtic, T., Sailor, W., \& Gee, K. (1996). Voice, collaboration, and inclusion: Democratic themes in educational and social reform initiatives. Remedial and Special Education 17, 142-157. doi:10.1177/074193259601700304

Slee, R. (2011). The irregular school: Exclusion, schooling, and inclusive education. London, England: Routledge.

Sobul, D. (1995). Specially designed academic instruction in English. Retrieved from https://files.eric.ed.gov/fulltext/ ED391357.pdf

Staub, D., \& Peck, C. (1995). What are the outcomes for nondisabled students? Educational Leadership, 52(4), 36-40.

Swedish Government Official Reports. (1948:27). 1946 - års skolkommissions betänkande med förslag till riktlinjer för det svenska skolväsendets utveckling [Guidelines for development of the Swedish school system. Report from the 1946 School Commission]. Stockholm, Sweden: Fritze.

Swedish National Agency for Education (2002). Skolverkets rapport nr 216. I särskola eller grundskola? [Swedish National Agency for Education report no 216. In special school or in compulsory school]Stockholm: Liber. Swedish National Agency for Education. (2018). Curriculum for the compulsory school, preschool class and school-age educare. Stockholm, Sweden: Author.

Swedish National Agency of Education (2019). PM - Pedagogisk personal i skola och vuxenutbildning läsåret 2018/19 [PM - Staff in schools and in education for adults schoolyear 2018/2019]. Diarenummer: 2019:46.

Swedish National Audit Office. (2019). Grundsärskolans kunskapsuppdrag - Styrning, stöd och uppföljning [The knowledge assignment in the CSSID - Steering, support and evaluation]. Stockholm, Sweden: Author.

Swedish Schools Inspectorate. (2010). Undervisningen i svenska $i$ grundsärskolan [The teaching in the Swedish compulsory school for students with intellectual disability]. Quality Review. Report 2010:9. Stockholm, Sweden: Skolinspektionen.

Swedish Schools Inspectorate. (2016). Integrerade elever - Undervisningssituationen för elever som är mottagna i grundsärskolan och får sin undervisning i grundskolan [Integrated pupils - The teaching situation for students who belongs in CSSID and receive their education in a regular primary school]. Diarienummer: 400-2015:6583.

Taub, D., Apgar, J., Foster, M., Ryndak, D. L., Burdge, M., \& Letson, S. (2019). Investigating the alignment between English language arts curricula developed for students with significant support needs and the CCSS. Remedial and Special Education. doi:10.1177/0741932519843184

Taub, D., McCord, J., \& Ryndak, D. L. (2017). Opportunities to learn for students with extensive support needs: A context of research-supported practices for all in general education classes. Journal of Special Education, 51, 127-137. doi:10.1177/0022466917696263 
Teachers Pay Teachers. (2019). Task boxes. Retrieved from https://www.teacherspayteachers.com/

Thompson, J., Walker, V., Shogren, K., \& Wehmeyer, M. L. (2018). Expanding inclusive educational opportunities for students with the most significant cognitive disabilities through personalized supports. Intellectual and Developmental Disabilities, 56, 396-411. doi:10.1352/19349556-56.6.396

Thurlow, M., Lazarus, S., Larson, E., Albus, D., Liu, K., \& Kwong, E. (2017). Alternate assessments for students with significant cognitive disabilities: Participation guidelines and definitions (NCEO Report 406). Minneapolis, MN: University of Minnesota, National Center on Educational Outcomes.

Timberlake, M. T. (2014). Weighing costs and benefits: Teacher interpretation and implementation of access to the general education curriculum. Research and Practice for Persons With Severe Disabilities, 39, 83-99. doi:10.1177/1540796914544547

Towles-Reeves, E., Kleinert, H., \& Muhomba, M. (2009). Alternate assessment: Have we learned anything new? Exceptional Children, 75, 233-252. doi:10.1177/001440290907500206

United Nations. Commission on Human Rights (1989). Convention on the Rights of the Child: text of the draft convention as adopted by the Working Group at second reading. [New York]: United Nations.

United Nations General Assembly (2007). Convention on the Rights of Persons With Disabilities: Resolution adopted by the General Assembly. Retrieved from https://www. un.org/development/desa/disabilities/resources/general-assembly/convention-on-the-rights-of-personswith-disabilities-ares61106.htm

U.S. Department of Education. (2003). Improving the academic achievement of the disadvantaged; final rule, 68 Federal Registry 236 (December 9, 2003) (codified at 34 C.F.R. pt. 200)

U.S. Department of Education. (2018). 40th annual report to Congress on the implementation of the Individuals With Disabilities Education Act. Retrieved from http://www. ed.gov

Wagner, M., Newman, L., Cameto, R., Levine, P., \& Garza, N. (2006). An overview of findings from Wave 2 of the $\mathrm{Na}$ tional Longitudinal Transition Study. Retrieved from the Institute of Education Sciences, National Center for Special Education Research website: https://ies. ed.gov/ncser/pdf/20063004.pdf

West, J. (2000). Back to school on civil rights: Advancing the federal commitment to leave no child behind. Washington, DC: National Council on Disability.

World Health Organization (WHO). (2001). International classification of functioning, disability, and health (ICF). Retrieved from https://www.who.int/classifications/icf/ en/

World Health Organization (WHO). (2011). World report on disability. Retrieved from https://www.who.int/disabilities/ world_report/2011/report.pdf
Yilmaz, Z., \& Topal, Z. (2014). Connecting mathematical reasoning and language arts skills: The case of Common Core State Standards. Procedia - Social and Behavioral Sciences, 116, 3716-3721. doi:10.1016/j.sbspro.2014.01.829

Young, K. (2008). "I don't think I'm the right person for that": Theoretical and institutional questions about a combined credential program. Disability Studies Quarterly, 28(4). doi:10.18061/dsq.v28i4.132 